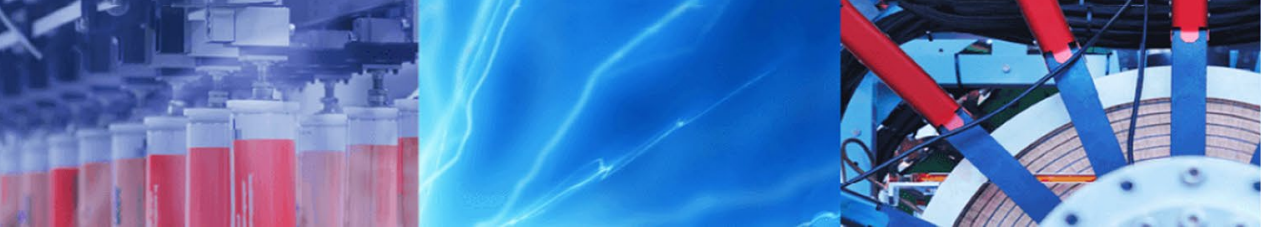

Research Article

\title{
Pyrolytic biochars from sunflower seed shells, peanut shells and Spirulina algae: their potential as soil amendment and natural growth regulators
}

\author{
Mariana P. Silva ${ }^{1,2} \cdot$ María L. Nieva Lobos $^{3} \cdot$ Roxana V. Piloni $^{3} \cdot$ Diego Dusso $^{3} \cdot$ María E. González Quijón $^{4}$. \\ Ana L. Scopel ${ }^{1,2}$ - Elizabeth L. Moyano ${ }^{3}$
}

Received: 21 May 2020 / Accepted: 16 October 2020 / Published online: 30 October 2020

(c) Springer Nature Switzerland AG 2020

\begin{abstract}
Several studies have shown that pyrolysis conditions and feedstocks are the key factors influencing biochar chemical and physical properties. The information on the nature of biochar is quite important, especially when this carbonaceous material is intended to be used as a potential soil amendment. In this study, we investigated the formation and characterisation of biochars produced from vacuum pyrolysis of sunflower seed shells (SSS), peanut shells (PS) and Spirulina algae (Sp) at $280^{\circ} \mathrm{C}$ (for SSS, PS and Sp) and $350^{\circ} \mathrm{C}$ (for PS). As a proxy to test the potential of each biochar as soil amendment, we assessed the germination and growth effects of the biochar water-extractable substances (BWES) at different concentrations $(10 ; 7.5 ; 5 ;$ and $2.5 \% \mathrm{w} / \mathrm{v}$ ) on Lactuca sativa. Results showed that the biochar from pyrolysis of PS at $280^{\circ} \mathrm{C}$ would be the most suitable soil amendment, since its BWES did not affect germination and exhibited a remarkable growth-promoting effect (50-100\%) on roots and stems of L. sativa.

In contrast, BWES from SSS, Sp and certain concentrations of PS produced at $350{ }^{\circ} \mathrm{C}$ inhibited growth of Lactuca sativa, and particularly BWES of Spirulina dramatically reduced germination, posing a risk for direct application as soil amendment. The presence of carbonyl derivatives in the BWES from PS may be linked to the stimulatory effects of this extract. Aromatics could be responsible for the germination and growth inhibition in the BWES of SSS, while nitrogen organic compounds would enhance the inhibitory effect in BWES from Sp.
\end{abstract}

Keywords Vacuum pyrolysis · Biochar water-extractable substances · Germination · Growth promotion · Phytotoxicity

\section{Introduction}

Industrial waste products may cause serious contamination problems, and alternative uses are continuously being explored in order to improve the efficiencies of the productive chain, reduce carbon and water footprints and increase overall sustainability [77].

The production of energy is one of the major forms of utilisation of these waste products [74], and a variety of biomass conversion technologies (hydrochemical, biochemical and thermochemical) are being implemented

Electronic supplementary material The online version of this article (https://doi.org/10.1007/s42452-020-03730-x) contains supplementary material, which is available to authorized users.

$\triangle$ Ana L. Scopel, scopel.ana@gmail.com; $\bowtie$ Elizabeth L. Moyano, lauramoy@fcq.unc.edu.ar|ㅌstación de Biología Sierras, Facultad de Agronomía-Delegación Punilla, Universidad de Buenos Aires, Casilda S/N, Huerta Grande, 5174 Córdoba, Argentina. ${ }^{2}$ Instituto de Investigaciones en Biociencias Agrícolas y Ambientales (INBA), Consejo Nacional de Investigaciones Científicas y Técnicas (CONICET), Buenos Aires, Argentina. ${ }^{3}$ INFIQC, Departamento de Química Orgánica, Facultad de Ciencias Químicas, Universidad Nacional de Córdoba, Córdoba, Argentina. ${ }^{4}$ Departamento de Ingeniería Química, Universidad de La Frontera, Temuco, Chile. 
and used as a source of energy to feed the same production system. Thermochemical conversion is increasingly being applied in industrial processes since it offers a clean and highly efficient technology that is easy to adapt to current energy infrastructures [35]. Among the thermochemical processes, pyrolysis has emerged as a promising front-end processing technology on the path to renewable fuels. During pyrolysis, biomass is rapidly heated in the absence of oxygen at temperatures between 300 and $600^{\circ} \mathrm{C}$ and converted into three main product categories: a solid biochar, non-condensable pyrolytic gases (e.g. CO, $\mathrm{H}_{2}, \mathrm{CO}_{2}$ ) and a liquid phase including an aqueous fraction and water insoluble oil [12]. In particular, vacuum pyrolysis produces high yields of bio-oils (main product) and a reactive biochar as a secondary product [65]. Such behaviour is due to the short residence time of the organic vapour generated in the reactor, which reduces the occurrence and intensity of secondary reactions [66].

From the industrialisation process of several agronomic oil crops, lignocellulosic wastes like sunflower and peanuts (seed shells and husks) can account for as much as $18-30 \%$ of the total biomass used in the process. Even considering the best scenario, in which the major industrial companies re-utilise these wastes for energy production, a residue-biochar-will be produced. This biochar may represent between 20 and $40 \%$ of the initial biomass, although magnitude will depend on initial feedstock and pre-treatments, the energy conversion process and setup conditions [36, 51]. Algal feedstocks are increasingly being used as a source of bio-oils and bio-products and can be produced under a wide range of biochemical and thermochemical technologies $[5,10]$. Pyrolysis of algae can lead to the production of $10-35 \%$ of a biochar enriched in several nutrients including minerals [10, 27, 61]. From the above, the production of biochar can be only predicted to augment as more activities will engage in the re-utilisation of waste products. Indeed, biochar has been proposed as a win-win technology to mitigate climate global change without affecting food security [32]. It has been the focus of increased research due to its multiplicity of beneficial applications $[15,23,31,52,71,79]$. Recent reviews on the agronomic benefits and drawbacks of biochar applications, including the effects on plant productivity, nutrient cycling, microbial interactions and carbon fate in the soil, conclude that biochar may be regarded as a promissory solution to energy, carbon sequestration and ecosystem function [11, 14, 39, 40, 79]. However, authors also warn on the risks of extrapolating results of untested materials and unexplored environments. Thus, before future largescale application of biochar becomes a common practice, biochar toxic effects and any other short- and long-term threats on biological organisms and their processes in the soil should be investigated in detail.
The most common negative effects reported for biochars relate to adsorbed compounds such as polycyclic aromatic hydrocarbons (PAHs) and heavy metals [24, 57, 63]. Although the extent to which these compounds are present in enough concentration and/or are bioavailable in the soil is somewhat controversial [40], some studies have shown that they may interfere with biological signalling within the rhizosphere and affect the soil biota [71].

Volatile organic compounds (VOCs) and particularly other potentially toxic elements and small organic compounds can be of further importance, since most of them remain in the solids during biochar production $[14,79]$ and could be easily leached when biochar is incorporated to the soil due to precipitation, or even by the presence of the water vapour-saturated atmosphere that is often present in the soil matrix [11, 29, 39, 81]. Studies on the effects of these leachates in bioassays have yielded mixed results and have been shown to depend on feedstocks, the thermo-conversion processes involved and production parameters $[3,9,18$, $20,50,51$ ]. Alburquerque et al. [4] found that biochar water extracts $(10 \% \mathrm{w} / \mathrm{v})$ from five lignocellulosic agricultural and forest wastes increased seed germination of sunflower relative to the controls, with calculated germination indexes above $60 \%$, typical of non-phytotoxic materials. In a previous work [68] in which we tested biochars' water extracts from pyrolysed leaves and shoots of Flourensia oolepis using Lactuca sativa as a test system, we found an amazing growth-promoting effect on roots (225\%) and shoots (160\%), and null or not permanent phytotoxic effect on germination. Lou et al. [48] found that biochar water extracts from wheat and maize significantly increased the yield and positively affected other ecophysiological parameters in potted cabbage experiments and concluded they had a great potential to be applied as liquid amendment. Rogovska et al. [63] reported no effect on corn seed germination but a decrease in seedling growth, in three out of six biochar extracts of different feedstocks obtained at the higher temperature treatments. Extracts from high volatile matter charcoal of macadamia nut shell $\left(430^{\circ} \mathrm{C}\right)$ reduced germination of radish and corn seeds [20]. Buss and Mašek [14] found that leachates of biochar produced from softwood pellets $\left(550^{\circ} \mathrm{C}\right)$ with high levels of VOCs induced heavy toxicity to germination of Lepidium sativum, while no phytotoxicity was observed for low-VOC biochars. Smith et al. [69] reported no phytotoxic effects of water-extractable substances form pyrolysed biochars of peanut seed husks and chicken litter on the growth of two blue-green algae, while negative effects were found for pinewood-derived biochar. Variable negative impacts on aquatic species of alga, bacteria, protozoa and crustaceans were also documented by Oleszczuk et al. [57] 
when biochar extracts from different feedstocks were tested. In spite of these contributions, the number of studies evaluating the characteristics of pyrolytic biochars and the phytotoxicity of their extracts is still very scarce $[69,73]$.

Physico-chemical characteristics of lignocellulosic agricultural wastes may differ largely among feedstocks which in turn determine their potential applications. Sunflower seed husks have been traditionally used as feed additives in a variety of animal production systems - from broilers to dairy cattle-[59], as an effective and cheap source for dyes adsorption in water media [78], or burned to produce heat power in oil-producing refineries. However, information about the use of this waste as a source for renewable energy is very scarce. Few studies describe the biochar yields and elemental composition of pyrolysis of sunflower seed husks at varying temperatures, and other authors have tested its biosorbent capacity for $\mathrm{Cu}^{2+}$ and methylene blue from industrial wastewaters [67, 72].

Peanut husks-derived biochars obtained under a variety of pyrolysis methods and operating conditions have been characterised in terms of elemental composition, CEC values and BET [43]. Several studies demonstrated the capacity of peanut hull biochars to adsorb different dyes and contaminants from aqueous solutions [26], wastewaters $[1,67]$ and heavy metals in soils [41]. Other authors have also shown that when applied as soil amendment to different soils, they may improve soil properties [55] and increase growth and yields of tested crops [46]. Qian et al. [62] showed that when used as a compound fertiliser at very low rates $\left(<1 \mathrm{t} \mathrm{ha}^{-1}\right)$, it could effectively reduce GHG emissions of rice crops. In the case of the non-cellulosic algae Spirulina (Arthrospira platensis), the few reports that describe biochar yields and its ultimate analysis for pyrolysed materials under different methods and temperatures suggested that due to its high C content, the biochar could be suitable for soil amendment and $C$ sequestration [27].

Although these residues are being extensively produced in major areas around the world, to the best of our knowledge no studies have yet evaluated the effects of these biochars' water extracts in bioassays as a proxy for their potential applications as soil amendments or to be incorporated in other soilless cultivation media. Therefore, the objectives of the present study were: (1) to determine product yields in the fast pyrolysis of sunflower seed shells, peanut shells and Spirulina, (2) to characterise the solid products (biochars) and evaluate their potential to be used as soil amendment through studying the effects of biochar water-extractable substances on germination and growth bioassays using Lactuca sativa, and (3) to identify the water-extractable organic compounds from the different biochars and correlate them with their bioactivity.

\section{Material and methods}

\subsection{Biomass samples: origin, processing and characterisation}

Sunflower seed shells (from now on SSS)-provided by Dr. M. A. Volpe (PLAPIQUI-UNS, Bahia Blanca, Argentina)-were pre-treated by growing Ganoderma lucidum on the shells, which allowed for a partial lignin degradation of the material [17]. Peanut shells (from now on PS) were obtained from AGD Company (Córdoba, Argentina). The blue-green alga Spirulina (Arthrospira platensis) (from now on Sp) was purchased to NuSci (USA) as dried powder (GB5009-2010). Characterisation of SSS, PS and Sp was performed by using various analytical techniques (Table 1). Elemental analysis was performed by a CHNS Elemental Analyzer 2400 Serie II (PerkinElmer Inc, USA). The lignin, hemicellulose and cellulose contents were determined by the Laboratorio de Servicios de Nutrición Animal (Faculty of Agronomy, University of Buenos Aires) using an ANKOM 200 Fiber Analyzer (ANKOM Technologies, USA), following the method described by Van Soest [82] as adapted by ANKOM ${ }^{\otimes} 2005$. Total ash content of each material was determined via combustion of the biomass at $575{ }^{\circ} \mathrm{C}$ according to standard test method for ash in biomass (ASTM E17551-01, 2015). The protein, lipids, moisture and carbohydrates contents were determined by the AOAC (2002) and FAO (2003) official methods of analysis.

Pyrolysis experiments The pyrolysis reactions were carried out in a horizontal quartz reactor under low pressures (0.01-0.05 Torr) and nitrogen flow of $0.05 \mathrm{~L}$

Table 1 Physico-chemical composition of the raw materials used in the pyrolysis experiments

\begin{tabular}{|c|c|c|c|}
\hline & SSS & PS & Sp \\
\hline$C(w t . \%)^{a}$ & 50.51 & 46.15 & 35.89 \\
\hline $\mathrm{N}(\mathrm{wt} . \%)^{\mathrm{a}}$ & 0.35 & 1.27 & 1.21 \\
\hline $\mathrm{H}(\mathrm{wt} . \%)^{\mathrm{a}}$ & 5.72 & 3.07 & 7.11 \\
\hline $\mathrm{O}(w t . \%)^{\mathrm{b}}$ & 30.7 & 35.94 & 33.58 \\
\hline $\mathrm{S}(w \mathrm{w} . \%)^{\mathrm{a}}$ & 0.09 & 0.08 & 0.01 \\
\hline Moisture (wt.\%) ${ }^{\mathrm{a}}$ & 11.2 & 8.8 & 3.6 \\
\hline Ash (wt.\%) ${ }^{a}$ & 1.43 & 4.69 & 18.6 \\
\hline Cellulose $\left(\mathrm{g} \mathrm{kg}^{-1}\right)^{\mathrm{c}}$ & 35 & 40.5 & - \\
\hline Hemicellulose $\left(\mathrm{g} \mathrm{kg}^{-1}\right)^{c}$ & 9 & 14.7 & - \\
\hline Lignin $\left(\mathrm{g} \mathrm{kg}^{-1}\right)^{\mathrm{c}}$ & 14 & 26.4 & - \\
\hline Crude fat (wt.\%) & - & - & 3.01 \\
\hline Crude protein (wt.\%) & - & - & 51.3 \\
\hline Carbohydrate (wt.\%) & - & - & 27.1 \\
\hline
\end{tabular}

a Dry basis, ${ }^{b}$ calculated by difference, cbiopolymer content determined by the reported method (wt\% dry basis) 
$\mathrm{min}^{-1}$ in a temperature range of $280-350{ }^{\circ} \mathrm{C}$. Temperatures were selected based on our previous results [68] and preliminary experiments in which biochar bioactivity could be detected. The pyrolysis unit consisted of a feeding system, a vacuum pyrolysis system and a condensation system, as previously described [53]. Biomass samples $(1.00 \mathrm{~g})$ were crushed and sieved to obtain particles of 10-20 mesh size and placed in a sliding quartz boat, which was fed into the pyrolysis furnace when temperature and vacuum settings were reached, and kept at these conditions for $20 \mathrm{~min}$. Due to the vacuum system, contact times of the generated products were very short $(<0.5 \mathrm{~s})$, in the same range of fast pyrolysis experiments. After the experiments were completed, the pyrolysate was extracted from the condenser with organic solvents. The yield of the liquid and char products was calculated by the weight difference of the condenser and the quartz boat, respectively, before and after the experiment. The yield of gas was calculated by the difference of starting biomass and generated pyrolysis oil and char. All yields are informed as the average of at least three experiments to verify the reproducibility of the reported results. Biochar generated in the pyrolysis experiments was characterised by elemental analysis in a CHNS Elemental Analyzer 2400Serie II (PerkinElmer Inc., USA). The $\mathrm{C} / \mathrm{N}$ and H/C atomic ratios were calculated from these results, and the content in oxygen was calculated by difference taking into account the ash content in the calculus. Ash content of biochar samples was determined by combustion method according to ASTM standards (ASTM D1762-84).

In the case of PS and SSS obtained at $280^{\circ} \mathrm{C}$, FT-IR spectrum was acquired using a microscope Thermo Scientific ${ }^{\mathrm{TM}}$ Nicolet $^{\mathrm{TM}} \mathrm{iN}^{\mathrm{TM}} 10$ (Thermo Fisher Scientific, USA) in its reflection mode, to see the decomposition degree. The powder X-ray diffraction (XRD) patterns were recorded in a diffractometer Panalytical X'Pert Pro (The Netherlands), using a Cu Ka $(\lambda=1.5418 \AA$ ) radiation with current conditions at $40 \mathrm{~mA}$ and voltage at $40 \mathrm{kV}$. The patterns were collected using a PIXcel 1D detector with 230 canals; each pattern was recorded between 10 and $70^{\circ}$ with a step of $0.026^{\circ}$ and with a time for step of $92.95 \mathrm{~s}$ at room temperature. The samples were taken using a single-crystal silicon sample port. Microcrystalline cellulose (99.5\%, Biopack, Argentina) was also measured for comparative purposes.

Nitrogen isotherms were determined at $-196{ }^{\circ} \mathrm{C}$ using a Quantachrome Nova 1000e sorptometer (Anton Paar Quantatec Inc., USA) by adsorbing and desorbing nitrogen at $77 \mathrm{~K}$ on samples previously dried and out-gassed at $160^{\circ} \mathrm{C}$ for $16 \mathrm{~h}$. BET equation was used for surface area calculations.

SN Applied Sciences

\subsection{Extraction and characterisation of biochar water-extractable substances}

Extraction of water-soluble substances from biochar was performed at $10 \%(\mathrm{w} / \mathrm{v})$ by soaking the solid sample material in distilled water. The biochar/water mixture was vortexed and placed at $22^{\circ} \mathrm{C}$ for $24 \mathrm{~h}$. This mixture was transferred to $15-\mathrm{mL}$ centrifuge tubes and centrifuged at $1500 \mathrm{rpm}$ and $15^{\circ} \mathrm{C}$ for 5 min using a Heraeus Labofuge 400R (Thermo Fisher Scientific, USA). The supernatants and pellets were collected separately. Then, the biochar/water mixture was filtered through a-Whatman grade 1-qualitative filter paper (11 $\mu \mathrm{m}$ pore size) via a $12-\mathrm{cm}$-diameter Buchner funnel. After extraction, the remnant biochar was dried $\left(50^{\circ} \mathrm{C}\right)$ yielding ca. $90 \%$ of the original weight.

In order to characterise the water-soluble organic compounds, the extracts from different biochars were evaporated at vacuum to constant weight and the residue was redissolved in acetone/methanol for analysis by gas chromatography coupled to mass spectra (GC/MS) or dissolved in $\mathrm{D}_{2} \mathrm{O}$ to perform the nuclear magnetic resonance experiments ( $(\mathrm{H}$ NMR).

GC/MS analyses of the samples were performed in a GC-MS-QP 5050 spectrometer (Shimadzu Corporation, Japan). The injector temperature was kept at $300^{\circ} \mathrm{C}$, and the separation was performed using a VF- $5 \mathrm{~ms}$ capillary column. Helium was used as a carrier gas with a constant flow rate of $0,5-1,0 \mu \mathrm{L} / \mathrm{min}$. The oven temperature was programmed from $80^{\circ} \mathrm{C}(3 \mathrm{~min})$ to $280^{\circ} \mathrm{C}(15 \mathrm{~min})$ with a heating rate of $10^{\circ} \mathrm{C} / \mathrm{min}$. The temperature of the GC/MS interface was held at $280^{\circ} \mathrm{C}$, and mass spectrometer was operated at $70 \mathrm{eV}$ under electron ionisation. The identification of chromatographic peaks corresponding to the main compounds was achieved according to NIST MS library (match $>90 \%$ ). Also, the identification of phenols was established by comparison with authentic samples.

${ }^{1} \mathrm{H}$ NMR spectra were recorded on a $400 \mathrm{MHz}$ spectrometer (Bruker Corporation, USA) at ambient temperature $\left({ }^{1} \mathrm{H}\right.$ at $400.16 \mathrm{MHz}$ and ${ }^{13} \mathrm{C}$ at $\left.100.9 \mathrm{MHz}\right)$. Solutions were typically prepared in deuterium oxide $\left(D_{2} O\right)$, with chemical shifts referenced to deuterated solvent as an internal standard. The proportion of aromatic compounds was calculated through integration of all protons corresponding to phenol derivatives and polycyclic aromatic hydrocarbons (PAHs), while the proportion of non-aromatics (carbonyl and nitrogenated derivatives) was calculated as the total of protons minus the aromatic protons.

\subsection{Bioassay of biochar water-extractable substances}

The bioactivity of biochar water extracts was evaluated on seeds of lettuce (Lactuca sativa, Grand Rapids). Twenty-five 
seeds were placed in a 5.0-cm Petri dish lined with one sheet of filter paper previously moistened with each test solution $(1.5 \mathrm{~mL})$ or distilled water in the case of controls and allowed to germinate in a growth chamber in the darkness at $22^{\circ} \mathrm{C}$. Three different bioassays with three replicates for each concentration were performed. Aqueous extracts were bio-assayed at $10 \%(\mathrm{w} / \mathrm{v})$ as well as serial dilutions with distilled water at 7.5, 5, 2.5 and $1.25 \%$. Seed germination was assessed at 24-h interval for three days as previously described [68]. A seed was considered germinated when root protrusion was evident (ca. $1 \mathrm{~mm}$ ). At day 3 , lengths of roots and shoots (hypocotyls) of $60 \%$ randomly chosen lettuce seedlings per Petri dish were determined, and relevant morphological features were also observed and annotated. Germination and growth responses expressed as a percentage of the controls were plotted against treatment concentrations. Where appropriate, effective concentrations capable of inhibiting $50 \%$ of germination, root growth or shoot growth were calculated as ECg50, ECr50 and ECs50, respectively. Additionally, seed viability of non-germinating seeds was tested in three to four seeds per Petri dish by means of the Tetrazolium test [19].

\subsection{Statistical analysis}

For the pyrolysis products yield, reported values correspond to the average of three replicate experiments and their respective standard deviation.

The bioassay results were analysed by ANOVA (REML) and DGCs test $(p<0.01)$, using InfoStat (National University of Córdoba, Argentina). Data are expressed as means of three independent bioassays (three replicates for each concentration (aqueous extracts) per bioassay) with their corresponding standard errors. Different letters $(a-b)$ indicate significant differences between treatment effects when compared to the control (ANOVA, REML and DGC test, $p<0.01$ ).

\section{Results and discussion}

\subsection{Characterisation of raw materials}

In lignocellulosic biomass feedstocks, the structural carbohydrates (cellulose and hemicellulose) and lignin polymers are the main organic constituents of plant cell walls, while fat, carbohydrates, and particularly proteins, are the key constituents of non-lignocellulosic materials as algae. Table 1 displays the contents of cellulose, hemicellulose and lignin of the sunflower and peanut seed shells (SSS and PS) and the fat, protein and carbohydrate values for
Spirulina (Sp) used in this study. Elemental analyses, ash and moisture are also shown.

Differences in biopolymers content were detected between SSS and PS biomasses. In SSS, these components represented $58 \%$ of the dry material, while in PS ca. $82 \%$ of the weight is accounted for the three polymers, being cellulose the main component. The major differences between feedstocks were detected in the hemicellulose and lignin content, being $1.6 \times$ and $1.9 x$ (respectively) larger in PS relative to SSS.

For SSS, the values for the three biopolymers were identical to those obtained by Casoni et al. [17] for mushroom pre-treated husks. Cellulose content falls within those found in other studies with untreated husks (27-48\%), but our values for hemicellulose and lignin were lower ( 9 vs. $13-35 \%$ and 14 vs. $17-37 \%$, respectively) $[7,16,21,34]$. A lower lignin value in our sample was expected based on the pre-treatment of the original material. Ash content was smaller than those previously reported [21, 47], Phyllis database (https://phyllis.nl/). In regard to the ultimate analysis of sunflower husks, values for $\mathrm{C}, \mathrm{H}, \mathrm{N}$ and $\mathrm{S}$ were within the range of those previously reported ( $C: 44-57.6$ wt\%, H: 5.6-6.5 wt\%, N: 0.33-5.8 wt\%, S: 0.05-0.31 wt\%), while $\mathrm{O}$ was significantly lower (O: 41.4-49 wt\%).

Peanut shells structural composition was very similar to that found by Jaishankar et al. [37], and within the range of those reported in previous papers [38, 84], Phyllis database). The ultimate analysis of PS showed that $\mathrm{C}$ and $\mathrm{N}$ values (Table 1) were similar to those found in the existing literature, while $\mathrm{H}$ and $\mathrm{O}$ were at the lower range of reported values (H: 2-7.50 wt\%, O: 33.9-50.85 wt\%) [38, 84], Phyllis database). Ash and moisture percentages were also within those reported previously.

In the case of Spirulina, protein levels fall within the $36-70 \mathrm{wt} \%$ range found in previous studies. Ortega-Calvo et al. [58] reported higher levels of fat (6.4-7.5 wt\%) and lower amounts of carbohydrates (12.6-18.8 wt\%). The ultimate analysis of our Sp sample showed $\mathrm{H}$ and $\mathrm{O}$ levels comparable with those previously reported $[27,58]$, while $C$ contents were up to $30 \%$ lower (42.8-53.4 wt $\%$ ). The major differences were detected in $\mathrm{N}$ and $\mathrm{S}$ contents, for which these authors reported up to $10 \times$ higher $\mathrm{N} \mathrm{lev-}$ els (4.1-12.4 wt\%) and $90 \times$ higher $\mathrm{S}(0.5-0.97 \mathrm{wt} \%)$. Moisture content was almost half of those previously reported (6.9-8 wt\%), while ash was 30 to ca. $150 \%$ higher (7-14 wt\%) (cf. values with Table 1).

\subsection{Pyrolysis of biomass}

The yields of the pyrolysis experiments for each type of the biomass are detailed in Table 2. For the lignocellulosic materials (SSS and PS), pyrolysis performed at these low temperatures resulted in high gas yields, followed 
Table 2 Distribution of products in the pyrolysis of biomass

\begin{tabular}{lllll}
\hline Biomass & $\mathrm{T}\left({ }^{\circ} \mathrm{C}\right)$ & \multicolumn{3}{l}{ Products } \\
\cline { 3 - 5 } & & Bio-oil & Biochar & Gas \\
\hline SSS & 280 & $22 \pm 1$ & $29 \pm 1$ & $49 \pm 3$ \\
PS & 280 & $25 \pm 2$ & $32 \pm 2$ & $43 \pm 4$ \\
& 350 & $18 \pm 3$ & $20 \pm 2$ & $61 \pm 4$ \\
Sp & 280 & $14 \pm 3$ & $49 \pm 1$ & $37 \pm 3$ \\
\hline
\end{tabular}

Mean \pm standard deviation

by biochar and bio-oil, while for the non-lignocellulosic Spirulina the production of biochar was clearly favoured (ca. 50\%).

Few reports have described the pyrolytic yields of SSS $[47,76]$ with highly varying results depending on the initial feedstock composition, pyrolysis system and temperatures. For instance, pre-treated SSS (w/ Ganoderma lucidum) transformed in a static system at $400{ }^{\circ} \mathrm{C}$ produced almost identical amounts of biochar (27\%), but higher bio-oil yields (34\%) and lower gas content (39\%) [17]. Zabaniotou et al. [76] studied the pyrolytic behaviour of sunflower shells within the range of $300-600{ }^{\circ} \mathrm{C}$ and found that maximum yields for each product were attained at different temperatures: $21 \mathrm{wt} \%$ bio-oil at $400{ }^{\circ} \mathrm{C}$, ca. $90 \mathrm{wt} \%$ biochar at $300^{\circ} \mathrm{C}$, and $53 \mathrm{wt} \%$ gas at $500^{\circ} \mathrm{C}$. Biochar and gas yields remained fairly constant within the $400-600{ }^{\circ} \mathrm{C}$ range, with $32-35 \%$ of biochar and $45-50 \%$ of gaseous products. Our reported values are almost identical to those found by these authors at a higher temperature $\left(280\right.$ vs. $\left.400^{\circ} \mathrm{C}\right)$.

The yields for the pyrolysed PS were strikingly similar to those recently reported by Lazzari et al. [42] but at a much higher temperature (i.e. $700{ }^{\circ} \mathrm{C}, 32 \%$ bio-oil, $32 \%$ biochar, $40 \%$ gas). Bio-oil yields were higher than those stated by Xie et al. [84] where they obtained $12-22 \%$ of oils for peanut shells of different granulometry subjected to $400-600{ }^{\circ} \mathrm{C}$. Biochar values reported here (32-20\%) are also within the range of those previously reported by other authors [26, 43].

In the case of Spirulina, a high yield of biochar was obtained at $280^{\circ} \mathrm{C}(49 \%$, Table 2 . This behaviour is different compared with previous studies where biochar yields did not exceed $31 \%$, even when different pyrolysis treatments and temperatures were used [27]. This increase in char formation could be attributed to the higher ash content present in the starting alga; we found $18.6 \mathrm{wt} \%$ of ashes, while these authors found values close to 7 $w t \%$. In fact, the promoting effect of higher percentages of ash-including metals and non-metal elements-in the original biomass in the formation of carbonaceous products has been previously reported [6].
Table 3 Characterisation of biochar derived from pyrolysis of the different biomasses

\begin{tabular}{|c|c|c|c|}
\hline & $\mathrm{B}-\mathrm{SSS}^{\mathrm{a}}$ & $B-P S^{b}$ & $B-S p^{C}$ \\
\hline$C(w t . \%)^{d}$ & 51 & 59 & 47 \\
\hline$N(w t . \%)^{d}$ & 2 & 2 & 8 \\
\hline$H(w t . \%)^{d}$ & 3 & 4 & 6 \\
\hline $\mathrm{O}(w t . \%)^{\mathrm{e}}$ & 22 & 32 & 13 \\
\hline Ash (wt.\%) & 2 & 3 & 26 \\
\hline Fixed carbon (wt.\%) & 54 & 58 & 43 \\
\hline Volatile matter (wt.\%) ${ }^{f}$ & 44 & 39 & 31 \\
\hline $\mathrm{H} / \mathrm{C}^{\mathrm{g}}$ & 0.7 & 0.8 & 1.5 \\
\hline $\mathrm{O} / \mathrm{C}^{\mathrm{g}}$ & 0.3 & 0.4 & 0.2 \\
\hline$S_{\mathrm{BET}}\left(\mathrm{m}^{2} \mathrm{~g}^{-1}\right)$ & 176.552 & 38.186 & 2.214 \\
\hline Pore volume $\left(\mathrm{cm}^{3} \mathrm{~g}^{-1}\right)$ & 0.038 & 0.007 & 0.003 \\
\hline
\end{tabular}

${ }^{\mathrm{a} B i o c h a r}$ derived from pyrolysis of sunflower seed shells at $280^{\circ} \mathrm{C}^{\mathrm{b}}$ Biochar derived from

pyrolysis of peanut shells at $280^{\circ} \mathrm{C}$

${ }^{\mathrm{C}}$ Biochar derived from pyrolysis of Spirulina at $280^{\circ} \mathrm{C}$

${ }^{\mathrm{d}}$ On dry basis

${ }^{\text {e}}$ Calculated by difference

${ }^{f}$ Calculated by difference

${ }^{g}$ Atomic ratio

\subsection{Characterisation of biochars}

The elemental composition, atomic ratios, ash content, fixed carbon, volatile matter, surface area and total pore volume of biochars are shown in Table 3.

Biochars from lignocellulosic materials (B-SSS and B-PS) showed similar elemental composition and atomic ratios compared to the non-lignocellulosic B-Sp (Table 1). B-SSS and B-PS showed higher $\mathrm{O}$ ( $w t \%, 1.7$ to $2.5 \mathrm{x}$ ) and $\mathrm{O} / \mathrm{C}$ ratios $(1.5-2 x)$, while $B-S p$ showed much higher levels of $\mathrm{N}(4 \mathrm{x})$ and of $\mathrm{H} / \mathrm{C}$ ratio (ca. $2 \mathrm{x}$ ). Ash content in B-Sp was 9 to $13 \times$ higher than in B-PS and B-SSS, respectively.

Typically, during pyrolysis an initial loss of surface functional $-\mathrm{OH}$ groups due to dehydration is expected, followed by $\mathrm{C}$-bound $\mathrm{O}$ and $\mathrm{H}$ atoms due to structural core degradation, although the rate and total losses of functional groups are strongly temperature dependent $[6,79]$. At the low temperatures used in these experiments, cellulose-type components may be expected in the biochars; however, the transformation of aliphatic cellulose molecules to aromatic components within the range of $250-400^{\circ} \mathrm{C}$ has also been reported (Wang and Xing [83]). FT-IR spectra and XRD profiles of PS- and SSS-derived biochars indicated that the cellulose component in original biomasses was transformed under pyrolysis conditions (Fig. $1 \mathrm{i}$, ii, Supplementary information). In IR spectra of biochars, the broadband between $3200-3650 \mathrm{~cm}^{-1}$ associated with $\mathrm{O}-\mathrm{H}$ stretching 
Fig. 1 Effects of biochar waterextractable substances (BWES) from the B-PS on germination and root and shoot growth of $L$. sativa, computed at the end of the experiment (day 3 ). Data are expressed as means of three independent bioassays (three replicates for each concentration (aqueous extracts) per bioassay) \pm SE. Different letters $(a-b)$ indicate significant differences between treatment effects when compared to the control (ANOVA, REML and DGC test, $p<0.01)$

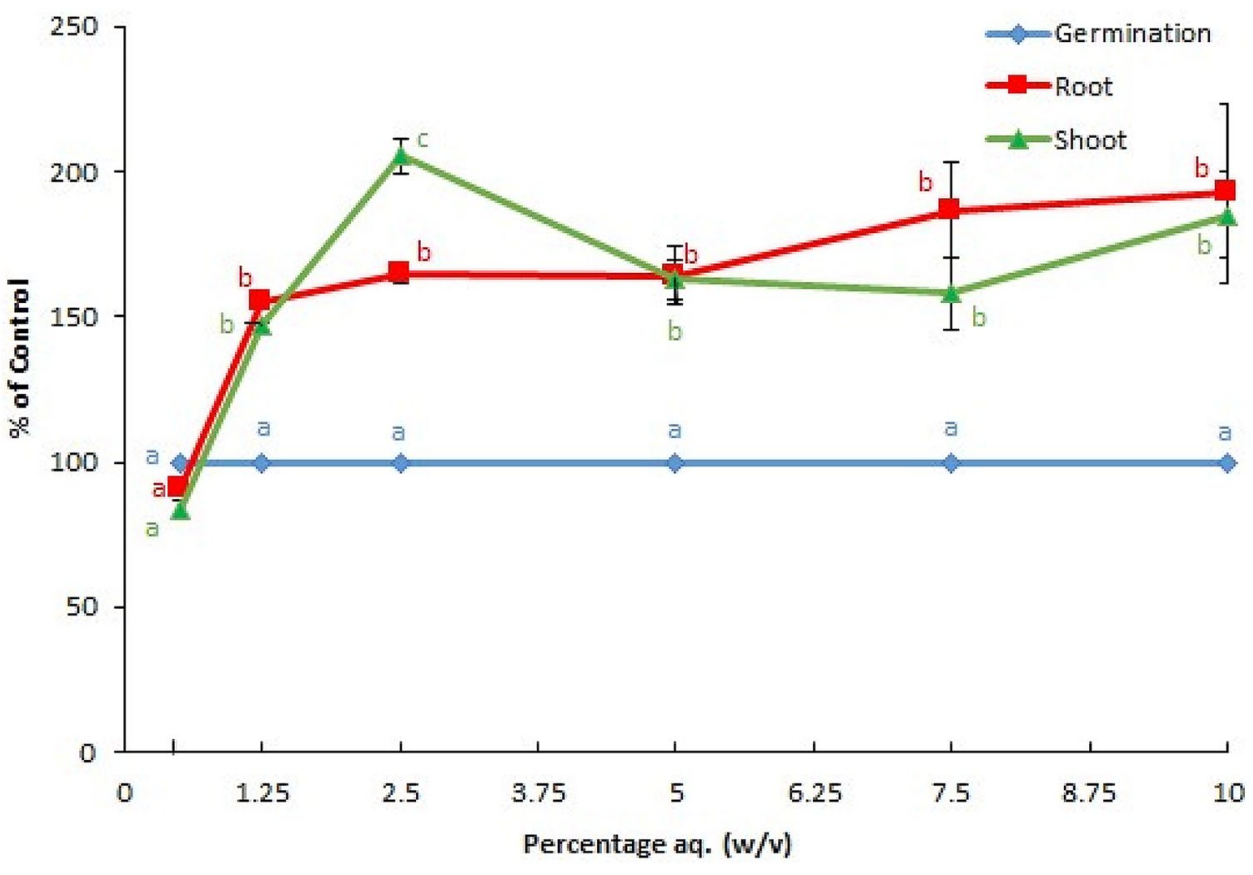

vibration mode of hydroxyl functional groups had a lower intensity than in pure cellulose. Other significative difference was the increment of bands between 1680 and $1520 \mathrm{~cm}^{-1}$ that can be assigned to $C=C$ vibrations in aromatic and olefinic region. The XRD patterns of biochars from PS and SSS showed two broad diffraction peaks corresponding to the typical peaks of carbon (Fig. $1 \mathrm{ia}, \mathrm{ib}, \mathrm{SI}$ ). The strongest peak located at $2 \Theta=20-30^{\circ}$ is attributed to the amorphous carbon structure, while the weaker diffraction peak at around $2 \Theta=40-50^{\circ}$ is assigned to the reflection from the incipient graphite component.

To the best of our knowledge, the characterisation of biochars from fast pyrolysis of SSS, PS and Sp at low temperatures is reported here for the first time, precluding any direct comparisons.

Reported data for biochars derived from sunflower husks have been obtained using diverse pyrolysis methods and temperatures $[67,72]$. These authors found relatively high $\mathrm{C}$ contents, which increased with temperature ( $\leq 60 \%$ at $\leq 300^{\circ} \mathrm{C}, \mathrm{ca} .72 \%$ at $400-500^{\circ} \mathrm{C}$ ), and a decrease in $\mathrm{H} / \mathrm{C}(0.11$ to 0.06$)$ and $\mathrm{O} / \mathrm{C}(0.75-0.34)$ as temperature increased $\left(240-500{ }^{\circ} \mathrm{C}\right)$. Compared to our results, these authors obtained similar percentages of O (21.8-24\%), H (3.7-4.5\%), N (0.91-2.64\%) and ashes (1.55-9.5\%). BET values were only reported by Saleh et al. [67] which found an extremely low surface area of $3.85 \mathrm{~m}^{2} \mathrm{~g}^{-1}$ compared to the $176.55 \mathrm{~m}^{2} \mathrm{~g}^{-1}$ found in our study, and higher total pore volume (cf. Table $3,0.124 \mathrm{vs.} 0.038 \mathrm{~cm}^{3} \mathrm{~g}^{-1}$ ). These results may be at least partially explained by the depleting effect that Ganoderma lucidum had on SSS lignin content (Table 1).
Peanut hulls-derived biochars have been characterised with different equipment and running conditions. Using a fluidised bed catalytic steam reformer $\left(475-481^{\circ} \mathrm{C}\right)$, Lee et al. [43] found higher C (>70\%), much lower $\mathrm{O}$ (15-16.6\%), but more similar $\mathrm{H}(2.9 \%)$ and $\mathrm{N}$ (ca. $2 \%)$ values compared to our results. A similar trend was observed in slow pyrolysis biochars produced using furnaces at temperatures between 300 and $700^{\circ} \mathrm{C}[26,85]$, particularly at the lower temperatures. These authors also found an increase in $\mathrm{C}$, and a decrease in $\mathrm{O}, \mathrm{H}$ and $\mathrm{N}$ as temperature increased. BET values reported by Yao et al. [85] were significantly lower compared with our results, even at the higher temperatures tested $\left(0.8-27.1 \mathrm{~m}^{2} \mathrm{~g}^{-1}, 300-600^{\circ} \mathrm{C}\right)$.

In Spirulina, Chaiwong and Kiatsiriroat [27] reported the results of biochars derived from slow and fast pyrolysis at $500{ }^{\circ} \mathrm{C}$. Their results showed similar $\mathrm{C}$ values $(45 \%$ and $39 \%$, respectively) to that found in this study, higher $\mathrm{O}(51 \%, 53 \%)$ and lower percentages of $\mathrm{N}(2.65 \%, 5.85 \%)$ and $\mathrm{H}(1.24 \%, 1.37 \%)$. Reported ash contents were 1.5 to $1.8 \times$ higher than the value obtained in our experiments.

\subsection{Bioassay of biochar water-extractable substances}

The biochar water extracts of the two agronomic wastes (B-SSS and B-PS) at $280^{\circ} \mathrm{C}$ did not affect the germination of Lactuca sativa seeds at any of the concentrations tested; and all the germinated seeds produced seedlings with normal morphology. However, a different pattern of response was observed between feedstocks regarding growth. B-PS water extracts exhibited a potent stimulatory 
effect on root and shoot growth (Fig. 1). Roots and shoots were 50 to $105 \%$ longer than the control at all concentrations $(1.25-10 \% \mathrm{w} / \mathrm{v})$. In contrast, B-SSS water extracts only promoted shoot growth at the lower range of concentrations $(1.25-2.5 \% \mathrm{w} / \mathrm{v}$ ) and to a lesser extent (up to $20 \%$ ) (Fig. 2). At these concentrations, root growth was unaffected, but it was substantially reduced (up to $40 \%$ ) at concentrations $\geq 5 \%(\mathrm{w} / \mathrm{v}$ ) relative to controls (Fig. 2).

BWES obtained from pyrolysis of peanut husks at $350^{\circ} \mathrm{C}$ (named as B-PS350) showed a totally different response compared to the same material pyrolysed at $280^{\circ} \mathrm{C}$, particularly regarding shoot and root growth (cf. Figs. 1 and 3. Although seed germination remained mostly unaffected, a reduction of ca. $40 \%$ was observed at the highest concentration as shown in Fig. 3. In contrast, root and shoot growth exhibited a V-shape response, in which ca. $75 \%$ reduction was observed at $5 \%(\mathrm{w} / \mathrm{v})$. While shoot growth was unaffected at the remainder concentrations, a significant reduction in
Fig. 2 Effects of biochar waterfrom the B-SSS on germination and root and shoot growth of $L$. sativa, computed at the end of the experiment (day 3). Data are expressed as means of three independent bioassays (three replicates for each concentration (aqueous extracts) per bioassay) \pm SE. Different letters $(a-b)$ indicate significant differences between treatment effects when compared to the control (ANOVA, REML and DGC test, $p<0.01$ ) extractable substances (BWES)

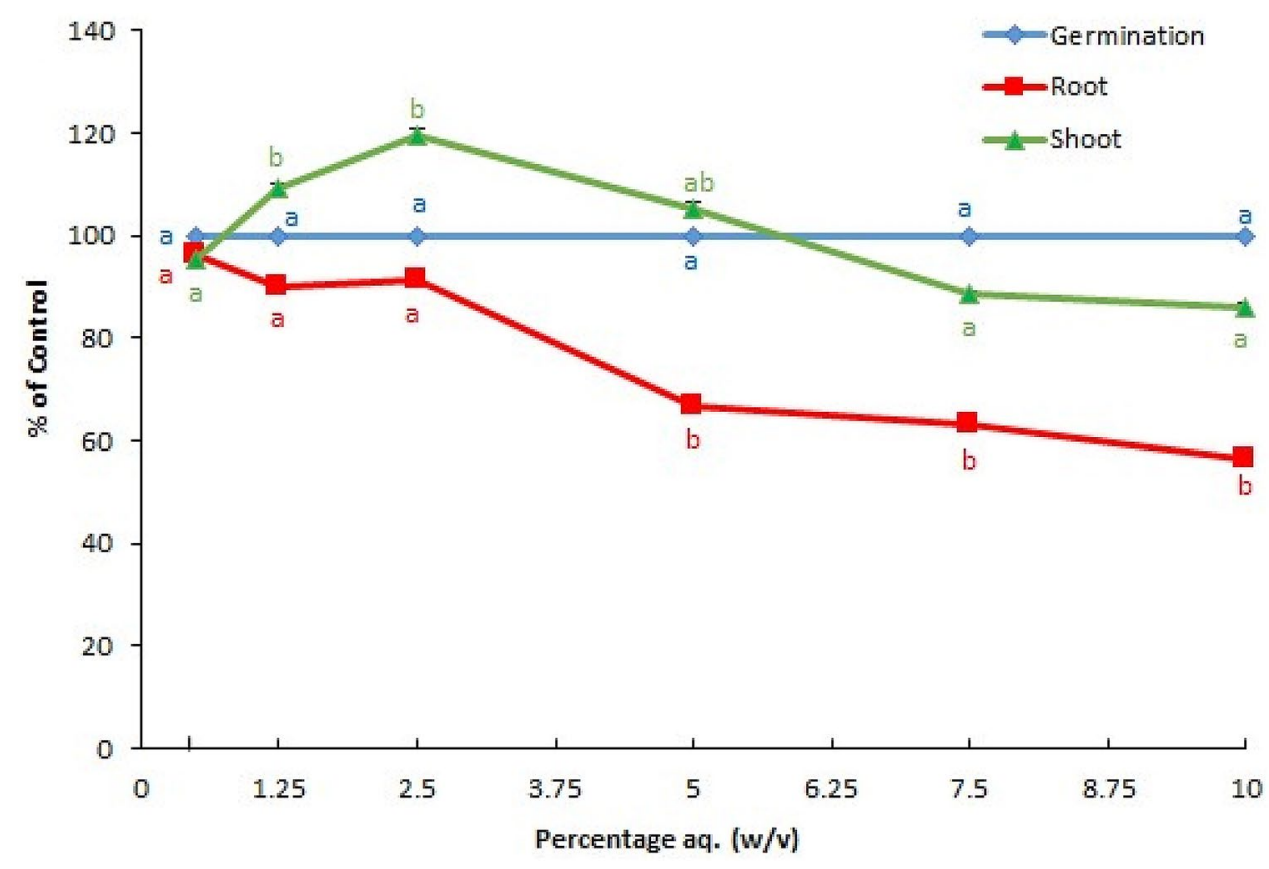

Fig. 3 Effects of biochar waterextractable substances (BWES) from B-PS350 on germination and root and shoot growth of $L$. sativa, computed at the end of the experiment (day 3). Data are expressed as means of three independent bioassays (three replicates for each concentration (aqueous extracts) per bioassay) $\pm S E$. Different letters $(a-d)$ indicate significant differences between treatment effects when compared to the control (ANOVA, REML and DGC test, $p<0.01)$

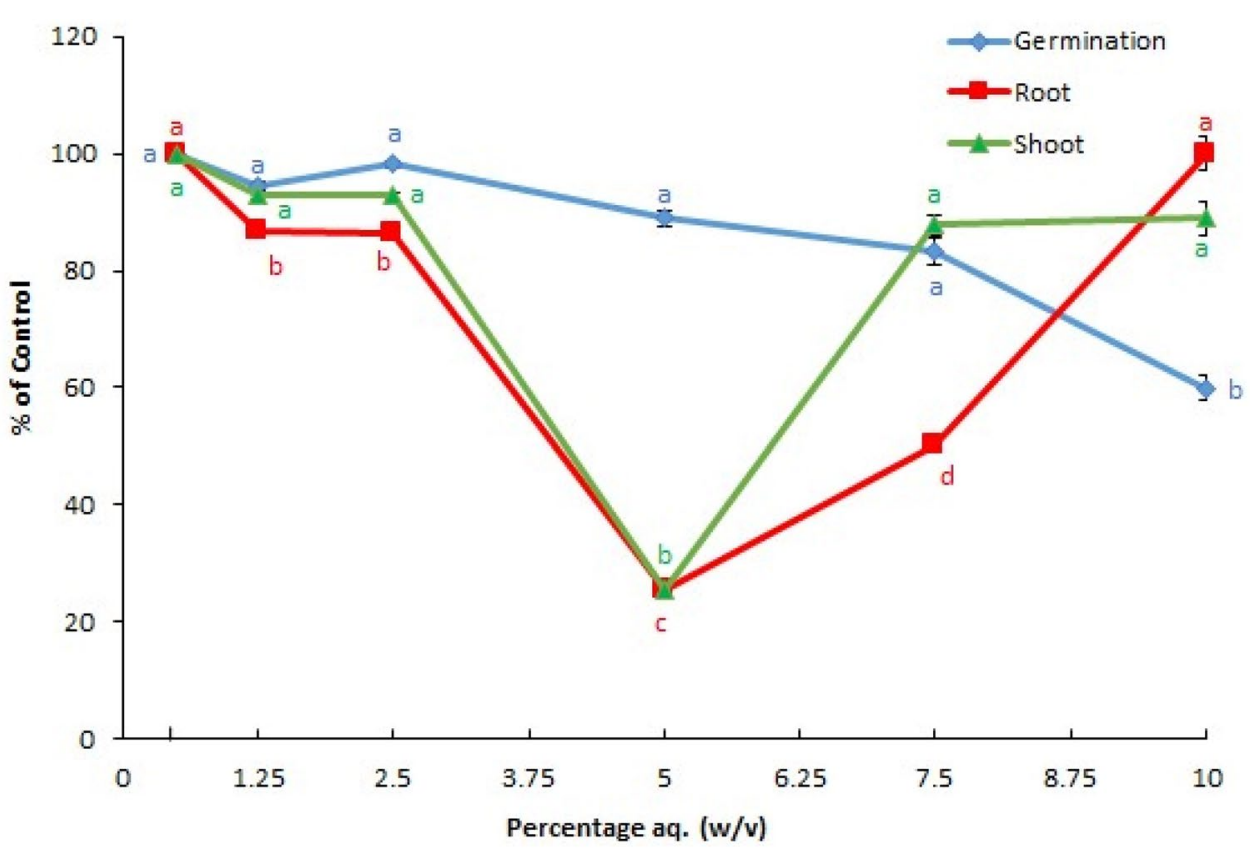


root growth (10-75\%) was observed in four of the five concentrations tested (1.25-7.5\% w/v) (Fig. 3).

The BWES from B-Sp, in turn, produced a drastic inhibition of $L$. sativa seed germination. At $1.25 \%(\mathrm{w} / \mathrm{v})$, germination was reduced by ca. $40 \%$; it was almost nil at 2.5 and $5 \%(\mathrm{w} / \mathrm{v})$ and completely inhibited at $\geq 7.5 \%$ (w/v) (Fig. 4).

Regarding growth, it was surprising that at the lowest concentration $(1.25 \% \mathrm{w} / \mathrm{v})$ shoot and root growth was promoted up to $20 \%$ relative to the controls. However, for the remainder concentrations root growth inhibition mimicked the response of seed germination, being severely affected at concentrations $\geq 2.5 \%$, and reaching $100 \%$ inhibition at $\geq 7.5 \%(\mathrm{w} / \mathrm{v})$. In contrast, shoot growth inhibition was visible at a higher concentration $(5 \% \mathrm{w} / \mathrm{v}$, $65 \%$ inhibition) and $100 \%$ inhibition occurred at concentrations $\geq 7.5 \%$ (w/v) (Fig. 4). The mean effective concentrations of the biochar water extract that inhibited germination (Ecg50), root (Ecr50) and shoot (Ecs50) growth were 2.6, 3.35 and $3.8 \%$, respectively.

The few reports in which germination bioassays have been performed with biochar water extracts have yielded variable results, depending on feedstocks, thermo-conversion processes involved and running conditions [3, 20, 51]. Using the same experimental protocol described here, we found that the biochar water extracts from pyrolysed leaves of Flourensia oolepis (at $280^{\circ} \mathrm{C}$ ) (B-FO) did not affect the viability of $L$. sativa seeds and only produced a transient arrest of germination at the higher concentrations ( 7.5 and $10 \% \mathrm{w} / \mathrm{v}$ ), which was overcome once the seeds were transferred to water [68]. Regarding seedling growth, B-FO water extracts showed a hormetic type of response, in which growth was enhanced at lower concentrations and inhibited at higher doses. In fact, a dramatic 225 to ca. $160 \%$ stimulatory effect was observed on root and shoot growth at concentrations between 1.5 and $5 \%(\mathrm{w} / \mathrm{v})$, while inhibition occurred at higher concentrations $(\geq 7.5 \% \mathrm{w} / \mathrm{v})$ [68].

In experiments performed with biochar water extracts from waste products, Alburquerque et al. [4] found increased germination of sunflower seeds when five different lignocellulosic agricultural and forest wastes (olive stone, almond shell, wheat straw, pine woodchips and olive tree pruning) were tested at $10 \% \mathrm{w} / \mathrm{v}$. Rogovska et al. [63] reported no effect on corn seed germination but a decrease in seedling growth, particularly shoot length, in three out of six biochar extracts derived from different feedstocks at the highest temperature treatments. The use of pyrolysed biochar leachates of coconut shells and wicker $\left(350-650^{\circ} \mathrm{C}\right)$ did not affect seed germination of Lepidium sativum and exerted a stimulatory effect (12 to $41 \%$ ) on root growth that was independent of the biochar concentration [57].

The presence of volatile organic compounds (VOCs) and water-soluble organic compounds (WSOCs) in biochars has been associated with both positive and negative biological effects (including plants, microorganisms and aquatic organisms) $[9,14,64,69]$. For instance, Deenik et al. [20] reported reduced germination of radish and corn seeds when subjected to high volatile matter charcoal extracts of macadamia nut shell $\left(430^{\circ} \mathrm{C}\right)$. Similarly, the leachates derived from softwood pellets biochar $\left(550^{\circ} \mathrm{C}\right)$ contaminated with high levels of VOCs caused phytotoxic effects on seed germination of $L$. sativum, while no phytotoxicity was observed in low-VOCs biochars [14]. It has also
Fig. 4 Effects of biochar waterextractable substances (BWES) from $B-S p$ on germination and root and shoot growth of $L$. sativa, computed at the end of the experiment (day 3). Data are expressed as means of three independent bioassays (three replicates for each concentration (aqueous extracts) per bioassay) $\pm S E$. Different letters $(a-d)$ indicate significant differences between treatment effects when compared to the control (ANOVA, REML and DGC test, $p<0.01$ )

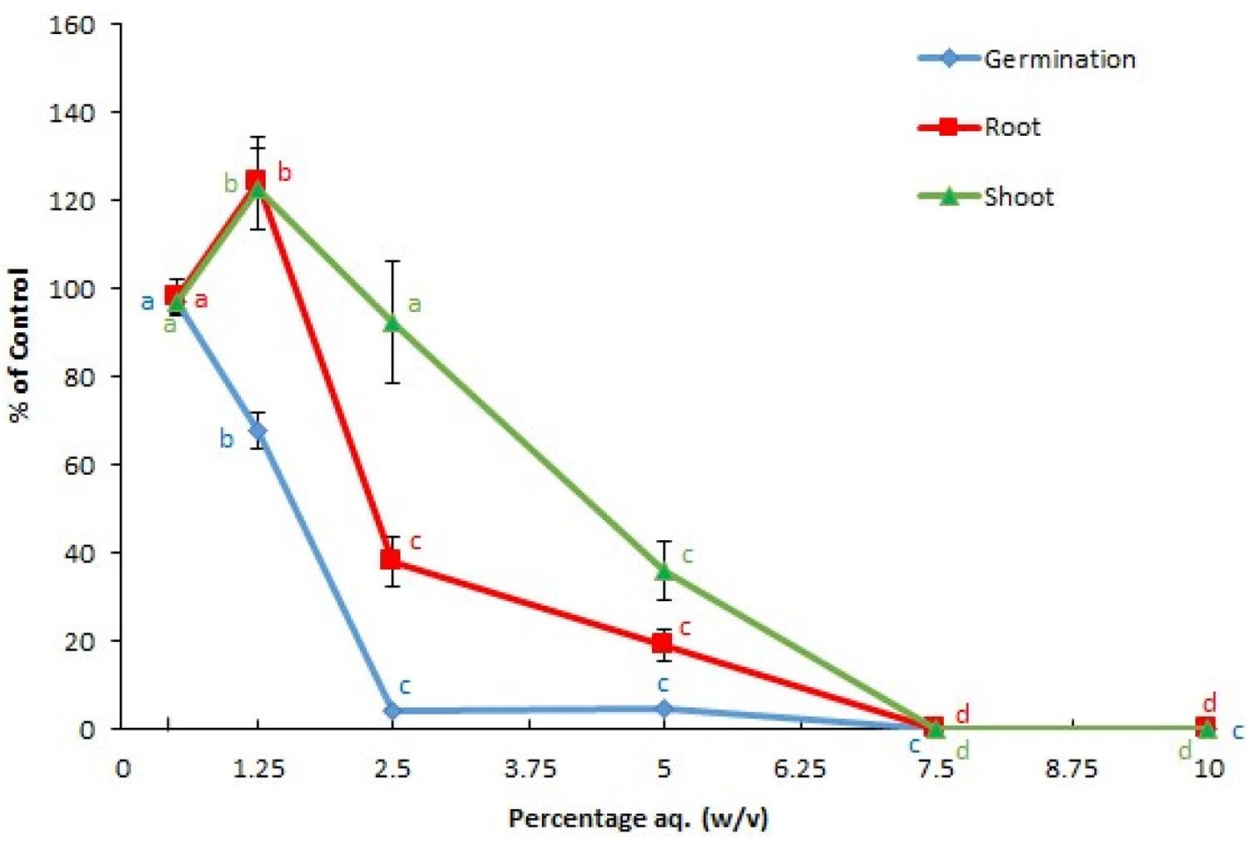

SN Applied Sciences 
been shown that the detrimental effects on germination may be significantly alleviated by different methods that reduce the phytotoxicity and number of VOCs $[13,63,64]$.

On the other hand, it was also found that the germination rate of $L$. sativum was unaffected by biochar extracts from pelletised corn stalks at $350-650{ }^{\circ} \mathrm{C}$ [28]. Similar results were obtained by Rombolà et al. [64] and were also consistent with those reported in a previous study in which corn stalk biochars with high contents of VOCs and WSOCs did not present inhibiting effects on seed germination [29]. Moreover, shoot growth was promoted in all treatments, and biochars with greater WSOCs content $\left(350-500{ }^{\circ} \mathrm{C}\right)$ exhibited longer shoots than those obtained at higher temperatures $\left(550-650^{\circ} \mathrm{C}\right)$, suggesting that WSOCs could be involved in the enhancement of plant growth. Backer et al. [9] also showed that VOCs and WSOCs from biosolids $\left(270^{\circ} \mathrm{C}-10 \mathrm{~min}, 320^{\circ} \mathrm{C}-20 \mathrm{~min}\right)$ and softwood chips $\left(500^{\circ} \mathrm{C}\right.$, slow pyrolysis) did not affect maize seed germination and shoot and root lengths after a 4-d incubation period, and even a stimulatory effect on shoot length was observed by the VOCs emitted by one of the biosolids $\left(320^{\circ} \mathrm{C}\right)$.

In investigations in which the growth of blue-green algae was tested against BWES, no phytotoxicity was found for pyrolysed peanut seed hulls and chicken litter, while negative effects were detected for pinewoodderived biochar [69]. Moreover, their results showed that peanut shell water extracts could even promote growth of the cyanobacterial culture (up to 60\%) when incubated at $1.13 \mathrm{~g} \mathrm{~L}^{-1}$. Authors determined that neither the differences in DOC (dissolved organic matter) nor $\mathrm{pH}$ values found in the water extracts of pinewood and peanut seed husks (DOC: $56.2 \%$ vs. $10.7 \%$, pH: 3.94 vs. 8.87 , respectively) were responsible for the observed responses, and proposed that other specific component(s) present in the water extracts would be contributing to the phytotoxicity in pinewood. In a subsequent in-depth study, Smith et al. [70] performed a molecular characterisation of the water-soluble components of this species and compared it to that found in the non-phytotoxic peanut-shell-derived biochar. Results showed important differences related to the $\mathrm{O} / \mathrm{C}$ and $\mathrm{H} / \mathrm{C}$ ratios, where pinewood water extracts were characterised by high ratios-more typical of carbohydrate-like compounds, whereas more formulas with lower ratios and an aromatic nature were found in peanut shells. The same authors proposed that phytotoxicity in pinewood biochar water extractables would be most probably related to degrade lignin-like species rich in oxygenated functionalities, like carboxyl, hydroxyl and methoxyl groups. In contrast, the non-phytotoxic peanut seed husks biochar water extracts seem not to contain these easily charged species. However, variable negative impacts on aquatic species of alga, bacteria, protozoa and crustaceans have also been documented for biochar extracts from different feedstocks (Miscanthus, coconut shell, wicker and wheat straw), where toxicity was closely related to the number of certain PAHs [57].

\subsection{Analysis and characterisation of BWES}

GC/MS and NMR analysis of the BWES of all residues confirmed the presence of a mixture of organic compounds, which can be classified in aromatics (phenols and polycyclic aromatic hydrocarbons) and non-aromatics (carbonyl and nitrogen derivatives). Some of these compounds were also detected in the pyrolytic oils of the investigated biomasses [54], indicating that the removal of these chemicals from the carbonaceous residue in the course of the pyrolysis process was not complete. All specific compounds were identified based on their mass spectra and the proton and carbon signals in the NMR experiments of the mixture, and their relative amount was calculated from the ${ }^{1} \mathrm{H}$ NMR spectrum.

In the case of the water extract from B-PS obtained at $280^{\circ} \mathrm{C}$, non-aromatic compounds were prevalent, with cyclic ketones and aldehydes as main contributors, while phenols and one polycyclic aromatic hydrocarbon (an anthracene derivative) were minor components (Table 4). Among the group of carbonyl compounds, 2-hydroxy3-methyl-cyclopenten-1-one and 3-methyl-imidazolidine2,4-dione were the major contributors. The abundance of the heterocyclic and the cyclic ketone compounds found in this extract may possibly be due to the specific pyrolytic process that favours the formation of such structures. The cyclopentenone derivative can be formed by degradation of carbohydrates during the early stages of the PS pyrolysis. The formation of imidazolidinedione, instead, seems complex; however, Sun et al. [75] have also detected similar heterocyclic compounds in the aqueous extracts from wheat and maize biochars. In turn, hydroxylated aromatics and PAHs are mainly formed from the degradation of the lignin component of PS, and it has been shown that these compounds can leach out from biochars into water extracts $[14,64]$.

B-PS350 water extracts showed a significant increase in aromatics relative to B-PS at $280^{\circ} \mathrm{C}$, with a preponderant contribution of phenolic compounds as guaiacol, creosol and eugenol, which have also been identified in the liquid fraction of pyrolysis [54].

The analysis of water-soluble organic compounds from B-SSS showed a high concentration of aromatics, as phenols and polycyclic hydrocarbons, while ketones and other carbonyl derivatives were detected in smaller quantities (Table 4).

It is important to stress that although the compounds found in the water extracts from B-PS and B-SSS were very 
Table 4 Composition of organic compounds in water extracts from biochars

\begin{tabular}{|c|c|c|c|}
\hline Extract & Non-aromatics ${ }^{\mathrm{a}}$ & Aromatics $^{\mathrm{a}}$ & $\begin{array}{l}\text { Ratio } \\
\text { Non-aro- } \\
\text { matics/ } \\
\text { Aromat- } \\
\text { ics }^{\text {b }}\end{array}$ \\
\hline$B-P S^{C}$ & $\begin{array}{l}\text { 2-Hydroxy-3-methyl-cyclopenten-1-one; } \\
\text { 3-Methyl-imidazolidine-2,4-dione } \\
\text { Aliphatic aldehydes }^{9}\end{array}$ & $\begin{array}{l}\text { Guaiacol, Eugenol, } \\
\text { PAHs }^{\mathrm{k}}\end{array}$ & 3.2 \\
\hline B-PS350 d & $\begin{array}{l}\text { 2-Hydroxy-3-methyl-cyclopenten-1-one; } \\
\text { Aliphatic aldehydes }{ }^{g}\end{array}$ & $\begin{array}{l}\text { Guaiacol, Eugenol, Creosol, } \\
\text { PAHs }\end{array}$ & 1.1 \\
\hline B-SSS & $\begin{array}{l}\text { 2-Hydroxy-3-methyl-cyclopenten-1-one; } \\
\text { 3-Methyl-2-cyclopenten-1-one; } \\
\text { Aliphatic aldehydes }{ }^{g} \text { and acids }\end{array}$ & $\begin{array}{l}\text { Guaiacol, Ethyl-guaiacol; Syringol; } \\
\text { 4-Hidroxy-2-methyl-acetophenone } \\
\text { PAHs }\end{array}$ & 2.0 \\
\hline$B-S p^{f}$ & $\begin{array}{l}\text { Cyclic and acyclic amines; } \\
\text { Long-chain aliphatic nitriles }^{j}\end{array}$ & $\begin{array}{l}\text { Phenol; } \\
\text { PHAs }\end{array}$ & 3.4 \\
\hline
\end{tabular}

${ }^{a}$ Compounds characterised by GC/MS and NMR spectroscopy. ${ }^{\mathrm{b}}$ Ratio of compounds determined by

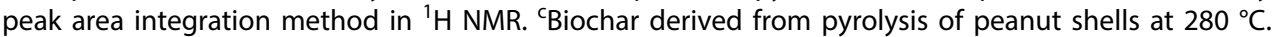
${ }^{\mathrm{d}}$ Biochar derived from pyrolysis of peanut shells at $350{ }^{\circ} \mathrm{C}$. ${ }^{e}$ Biochar derived from pyrolysis of sunflower seed shells at $280^{\circ} \mathrm{C}$. 'Biochar derived from pyrolysis of Spirulina at $280^{\circ} \mathrm{C}$. ${ }^{9}$ Butanal, octanal and octadecenal. hPalmitic acid, octadecenoic acid. 'Piperazine, 4-amino-4-methyl-2-pentanone and aliphatic amines. ${ }^{j}$ Hexanedecanenitrile and pentadecanenitrile. ${ }^{k}$ Polycyclic aromatic hydrocarbons (anthracene derivatives) similar, the concentration of these derivatives changed in each case. The calculated ratios between non-aromatics/ aromatics were 3.2, 1.1 and 2 for B-PS, B-PS280 and BSSS, respectively (Table 4). The differential contribution of these categories may explain the different bioactivities exhibited by these BWES.

In contrast, the water extract obtained from B-Sp showed a totally different composition (Table 4). As expressed by the non-aromatics/aromatics ratio (i.e. 3.4), there was a clear preponderance of non-aromatic nitrogenated compounds, mainly represented by cyclic and acyclic amines and long-chain nitriles, while aromatics were minoritary (only phenol and one polycyclic hydrocarbon).

A van Krevelen diagram (Fig. 5) was used to visualise the possible differences among the various biochar's water extracts based on the relative $\mathrm{H} / \mathrm{C}$ and $\mathrm{O} / \mathrm{C}$ atomic ratios of the molecular formulas of the detected organic compounds (Table 4). According to the stoichiometric ranges used to establish boundaries of the chemical classification space for the components found in natural organic materials, regions can be considered as: proteins $(\mathrm{H} / \mathrm{C}=1.5-2.2$ and $\mathrm{O} / \mathrm{C}=0.3-0.67)$, lipids $(\mathrm{H} / \mathrm{C}=1.5-2.0, \mathrm{O} / \mathrm{C}=0-0.3)$, lignins $(\mathrm{H} / \mathrm{C}=0.7-1.5$ and $\mathrm{O} / \mathrm{C}=0.1-0.67)$, carbohydrates
Fig. 5 Van Krevelen diagram of detected compounds in BWES from B-PS, B-PS350, B-SSS and B-Sp

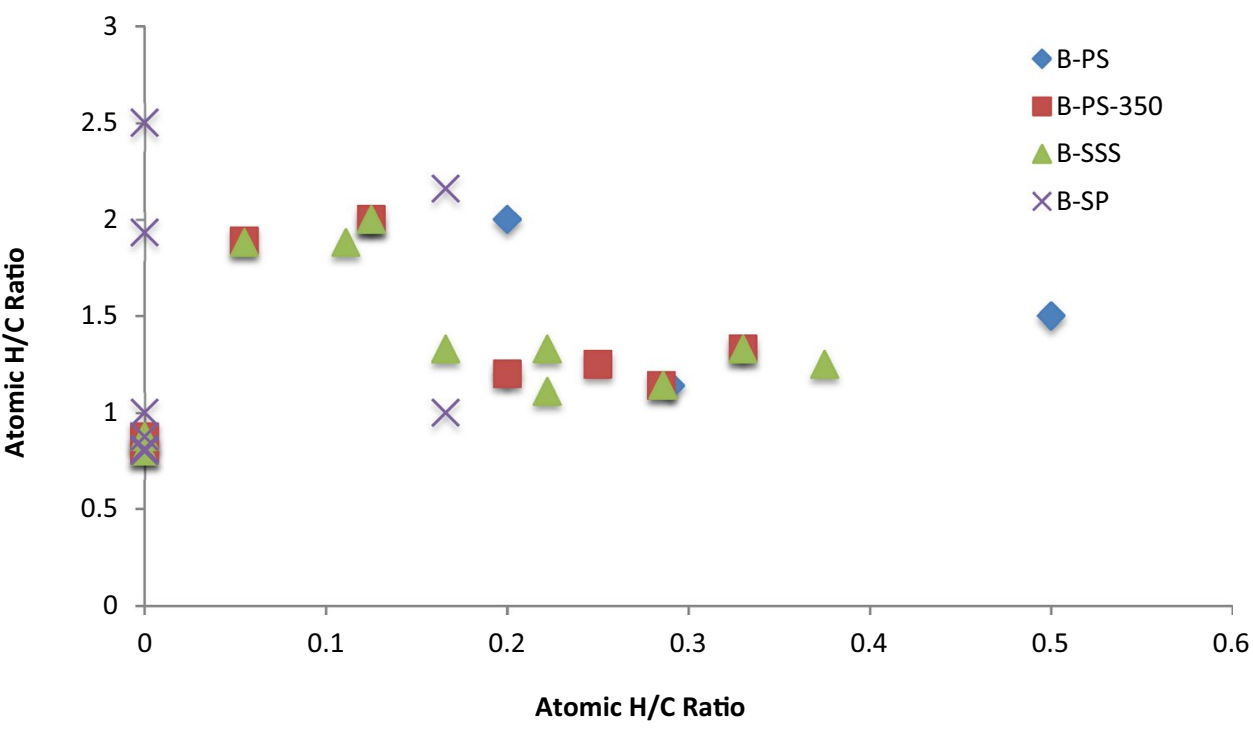

SN Applied Sciences 
$(\mathrm{H} / \mathrm{C}=1.5-2.4$ and $\mathrm{O} / \mathrm{C}=0.67-1.2)$, unsaturated hydrocarbons $(\mathrm{H} / \mathrm{C}=0.8-1.5$ and $\mathrm{O} / \mathrm{C}=0-0.1)$ and polycyclic aromatics $(\mathrm{H} / \mathrm{C}=0.2-0.8$ and $\mathrm{O} / \mathrm{C}=0-0.67)$. The plot derived from the compounds determined in Table 4 shows a distribution pattern that is strongly dependent on biochar origin, with the majority of the components corresponding to lignin, protein, lipids and condensed aromatics (Fig. 5).

The diagram also shows proximity of the molecules detected in B-PS350 and B-SSS, which is consistent with the fact that both water extracts share $50 \%$ of the total molecules detected. Less overlap is observed for B-PS, where compounds are more dispersed along the two axes and where two distinct molecules (3-methyl-imidazolidine-2,4-dione and butanal) exclusively found in this extract are visualised.

In contrast, in the case of the B-Sp, the mixture of compounds is mainly clustered at the far left side of the diagram. This distribution clearly obeys to the particular composition found in this extract, in which $75 \%$ of the total compounds (nitrogenated and PAH) do not have oxygen atoms.

It is also worthy to note that B-SS and B-Sp showed a larger number of exclusive compounds that were not present in B-SPs extracts, which represented as much as 50\% and $75 \%$ of the total for each extract, respectively.

Regarding the chemical nature of the BWES and correlating them with their effects on germination and growth of root/shoot of $L$. sativa, it can be strongly suggested that the increase in the concentration of aromatic compounds for B-PS and B-SSS may be responsible for the observed reduction in germination and growth. These results are in line with the toxicity of biochar water-soluble organic compounds described previously in the literature [25]. It is known that negative effects of BWES on seed germination, soil microbes and aquatic microorganisms, among others, can be associated with the presence of PAHs [63], dioxins [33], phenols and organic acids [14, 64]. In our study, the water extracts of B-PS and B-SSS showed a far greater contribution of phenol derivatives relative to PAHs. However, without specific experiments, it is difficult to assure that only one of these classes is completely responsible for the observed toxicity.

In the case of BWES derived from B-Sp and taking into account the predominance of nitrogen organic (nonaromatic) compounds over aromatics, amines and nitriles could lead to the detected detrimental effects on germination and growth of L. Sativa.

The stimulatory growth effect on roots and stems of $L$. sativa produced by B-PS water extracts could be attributed to the presence of imidazolidinedione and/or cyclopentenone derivatives, present in large amounts in the leachate. In this regard, it is worth mentioning that heterocyclic nitrogen compounds identified in the water extract from maize biochar have been indicated as responsible for the enhanced germination of maize seed and seedling growth [75]. The fact that the water extract from B-PS at $280^{\circ} \mathrm{C}$ was the only one exhibiting promoting growth activity at all concentrations tested, and that the imidazolidinedione derivative was solely found in this extract, strongly suggests the involvement of this compound in the growth-promoting activity; however, a direct implication of this carbonyl compound (or other) in the observed response would deserve further testing.

\section{Conclusions}

To the best of our knowledge, this is the first report in which the bioactivity of the biochar water extracts derived from sunflower seed shells, peanut shells and Spirulina have been tested against the germination and growth of Lactuca sativa as a test system, and the first to document the bioactivity, specifically the phytotoxicity of Spirulina.

The experimental approach using BWES is a good proxy when trying to mimic the fate of the biochar incorporated into the soil matrix relative to the leaching of waterextractable substances. Within the soil, biochars will be exposed to wet-dry cycles under rain and/or irrigation, where leaching will be favoured during soil wetting. In this sense, our results show that B-PS at $280^{\circ} \mathrm{C}$ would be the most suitable soil amendment, since its BWES not only did not affect germination but exhibited an outstanding stimulatory growth effect on both roots and stems of $L$. sativa. The inhibitory effects of B-PS350, B-SSS and B-Sp, even present at the lower range of concentrations tested, would indicate that their direct incorporation into the soil would not be advisable without further, in-depth studies.

In addition, the promoting growth effect of BWES of peanut shells strongly suggests that these extracts could be used as growth enhancers or biostimulants, providing a high-valued by-product that could be obtained prior to its incorporation into the soil. Carbonyl compounds (heterocyclic and/or carbocyclic) could be responsible for these stimulatory effects with hormone-like activity. On the other hand, the remarkable germination inhibition detected in BWES of Spirulina allows speculating on its potential application as natural herbicide, where the nitrogen organic compounds would be responsible for the inhibitory effects. However, the possible influence of the mineral fraction present in the ashes, particularly in B-SSS and B-Sp, on the observed responses cannot be ruled out.

Acknowledgments This work was supported by CONICET and SECYT-Universidad Nacional de Córdoba. The authors thank Dr. Gloria Bonetto for her assistance in NMR experiments. On behalf of all authors, the corresponding authors state that there is no conflict of interest. 


\section{Compliance with ethical standards}

Conflict of interest The authors declare that they have no conflict of interest.

\section{References}

1. Ahmad M, Lee SS, Dou X, Mohan D, Sung JK, Yang JE, Ok YS (2012) Effects of pyrolysis temperature on soybean stover-and peanut shell-derived biochar properties and TCE adsorption in water. Bioresour Technol 118:36-54

2. Ahmad M, Rajapaksha A, Lim J, Zhang M, Bolan N, Mohan D, Vithanage M, Lee S, OkY (2014) Biochar as a sorbent for contaminant management in soil and water: a review. Chemosphere 99:19-33

3. Ahmed H, Schoenau J (2015) Effects of biochar on yield, nutrient recovery, and soil properties in a Canola (Brassica napus $\mathrm{L}$ )-wheat (Triticum aestivum $\mathrm{L}$ ) rotation grown under controlled environmental conditions. Bioenergy Res 8:1183-1196

4. Alburquerque JA, Calero JM, Barrón V, Torrent J, del Campillo MC, Gallardo A, Villar R (2014) Effects of biochars produced from different feedstocks on soil properties and sunflower growth. J Plant Nutr Soil Sci 177:16-25

5. Amin S (2009) Review on biofuel oil and gas production processes from microalgae. Energy Convers Manage 50:1834-1840

6. Antal MJ Jr, Grønli M (2003) The art, science, and technology of charcoal production. Ind Eng Chem Res 42:1619-1640

7. Antal MJ, Allen SG, Dai X, Shimizu B, Tam MS, Grønli M (2000) Attainment of the theoretical yield of carbon from biomass. Ind Eng Chem Res 39:4024-4031

8. Atkinson C, Fitzgerald J, Hipps N (2010) Potential mechanisms for achieving agricultural benefits from biochar application to temperate soils: a review. Plant Soil 337:1-8

9. Backer R, Ghidotti M, Schwinghamer T, Saeed W, Grenier C, Dion-Laplante C, Fabbri D, Dutilleul P, Seguin P, Smith DL (2018) Getting to the root of the matter: Water-soluble and volatile components in thermally-treated biosolids and biochar differentially regulate maize (Zea mays) seedling growth. PLoSONE 13:e0206924

10. Brennan $L$, Owende $P$ (2010) Biofuels from microalgae-A review of technologies for production, processing, and extractions of biofuels and co-products. Renew Sustain Energy Rev 14:557-577

11. Biederman L, Harpole W (2015) Biochar and its effects on plant productivity and nutrient cycling: a meta-analysis. GCB Bioenergy 5:202-214

12. Bridgwater $A$ (2004) Biomass fast pyrolysis. Therm Sci 8:21-49

13. Busch D, Stark A, Kammann Cl, Glaser B (2013) Genotoxic and phytotoxic risk assessment of fresh and treated hydrochar from hydrothermal carbonization compared to biochar from pyrolysis. Ecotoxicol Environ Saf 97:59-66

14. Buss W, Mašek O (2014) Mobile organic compounds in biochar-a potential source of contamination-phytotoxic effects on cress seed (Lepidium sativum) germination. J Environ Manag 137:111-119

15. Cai Y, Qi H, Liu Y, He X (2016) Sorption/desorption behavior and mechanism of $\mathrm{NH}_{4}^{+}$by biochar as a nitrogen fertilizer sustainedrelease material. J Agric Food Chem 64:4958-4964

16. Cancalon PF (1971) Chemical composition of sunflower seed hulls. J Am Oil Chem Soc 48:629-632

17. Casoni A, Bidegain M, Cubitto M, Curvetto N, Volpe M (2015) Pyrolysis of sunflower seed hulls for obtaining bio-oils. Bioresour Technol 177:406-409
18. Chandra S, Bhattacharya J (2019) Influence of temperature and duration of pyrolysis on the property heterogeneity of rice straw biochar and optimization of pyrolysis conditions for its application in soils. J Clean Prod 215:1123-1139

19. Copeland LO, McDonald MB (1985) Principles of Seed Science and Technology, 2nd edn. Burguess Publishing Company, Minneapolis, p 329

20. Deenik J, Diarra A, Uehara G, Campbell S, Sumiyoshi Y, Antal Jr.M, (2011) Charcoal ash and volatile matter effects on soil properties and plant growth in an acid ultisol. Soil Sci 176:336-345

21. Demirbas A (2002) Fuel characteristics of olive husk and walnut, hazel nut, sunflower and almond shells. Energy Sour 23:215-221

22. Elad Y, Cytryn E, Meller Harel Y, Lew B, Graber ER (2011) The biochar effect: plant resistance to biotic stresses. Phytopathol Mediterr 50:335-349

23. Ennis CJ, Evans AG, Islam M, Ralebitso-Senior TK, Senior E (2012) Biochar: carbon sequestration land remediation and impacts on soil microbiology. Crit Rev Environ Sci Technol 42:2311-2364

24. Fabbri D, Rombolà AG, Torri C, Spoka KA (2012) Determination of polycyclic aromatic hydrocarbons in biochar and biochar amended soil. J Anal Appl Pyrol 103:60-67

25. Freddo A, Cai C, Reid BJ (2012) Environmental contextualization of potential toxic elements and polycyclic aromatic hydrocarbons in biochar. Environ Pollut 171:18-24

26. Gai X, Wang H, Liu J, Zhai L, Liu S, Ren T, Liu H (2014) Effects of feedstock and pyrolysis temperature on biochar adsorption of ammonium and nitrate. PLOS ONE 9:e113888

27. Chaiwong K, Kiatsiriroat $\mathrm{T}$ (2015) Characterizations of bio-oil and bio-char products from algae with slow and fast pyrolysis. Int J Environ Bioenergy 10:65-76

28. Ghidotti M, Fabbri D, Hornung A (2017) Profiles of volatile organic compounds in biochar: insights into process conditions and quality assessment. ACS Sustain Chem Eng 5:510-517

29. Ghidotti M, Fabbri D, Mašek $O$, Logan Mackay $C$, Montalti M, Hornung A (2017) Source and biological response of biochar organic compounds released into water. Relationships with biooil composition and carbonization degree. Environ Sci Technol 51:6580-6589

30. Glaser B, Lehmann J, Zech W (2002) Ameliorating physical and chemical properties of highly weathered soils in the tropics with bio-char-A review. Biol Fertil Soils 35:219-230

31. Gupta S, Kua HW, Koh HJ (2018) Application of biochar from food and wood waste as green admixture for cement mortar. Sci Tot Environ 619-620:419-435

32. Gurwick NP, Moore LA, Kelly C, Elias P (2013) A systematic review of biochar research, with a focus on its stability in situ and its promise as a climate mitigation strategy. PLoS ONE 8:e75932

33. Hale SE, Lehmann J, Rutherford D, Zimmerman AR, Bachmann RT, Shitumbanuma V, O'Toole A, Sundqvist KL, Arp HPH, Cornelissen $G$ (2012) Quantifying the total and bioavailable polycyclic aromatic hydrocarbons and dioxins in biochars. Environ Sci Technol 46(5):2830-2838

34. Heuzé V, Tran G, Hassoun P, Lessire M, Lebas F (2018) Sunflower hulls and sunflower screenings. Feedipedia, a programme by INRA, CIRAD, AFZ and FAO. https://www.feedipedia.org/ node/733. (accessed Dec 15)

35. Huber GW, Iborra S, Corma A (2006) Synthesis of transportation fuels from biomass: chemistry, catalysts and engineering. Chem Rev 106:4044-4098

36. Igalavithana $A D$, Mandal $S$, Niazi NK, Vithanage M, Parikh SJ, Mukome FND, Rizwan M, Oleszczuk P, Al-Wabel M, Bolan N, Tsang DCW, Kim K-H, Ok YYS (2017) Advances and future directions of biochar characterization methods and applications. Crit Rev Environ Sci Technol 47:2275-2330 
37. Jaishankar M, Mathew BB, Shah MS, Tp KM, Kr SG (2014) Biosorption of few heavy metal ions using agricultural wastes. J. Environ. Poll. Hum Health 2:1-6

38. Kiran BM, Srikantaswamy S, Pallavi HV, Manoj V, Tasneem T (2013) A study on utilization of groundnut shell as biosorbent for heavy metals removal. J Environ Sci Comput Sci Eng Tech 2:173-186

39. Kookana R, Sarmah A, Van Zwieten L, Krull E, Singh B (2011) Chapter three-biochar application to soil: agronomic and environmental benefits and unintended consequences. Adv Agron 112:103-143

40. Kuppusamy S, Thavamani P, Megharaj M, Venkateswarlu K, Naidu $R$ (2016) Agronomic and remedial benefits and risks of applying biochar to soil: current knowledge and future research directions. Environ Int 87:1-12

41. Lahori AH, Guo Z, Zhang Z, Li R, Mahar A, Awasthi MK, Shen F, Sial TA, Kumbhar F, Wang P, Jiang S (2017) Use of biochar as an amendment for remediation of heavy metal-contaminated soils: prospects and challenges. Pedosphere 27:991-1014

42. Lazzari E, Schena T, Marcelo MCA, Primaza CT, Silva AN, Ferrão MF, Bjerkc T, Bastos Caramão E (2018) Classification of biomass through their pyrolytic bio-oil composition using FTIR and PCA analysis. Ind Crops Prod 111:856-864

43. Lee JW, Hawkins B, Kidder MK, Evans BR, Buchanan AC, Day D (2016) Characterization of biochars produced from peanut hulls and pine wood with different pyrolysis conditions. Bioresour Bioprocess 3:15

44. Lehmann J, Gaunt J, Rondon M (2006) Biochar sequestration in terrestrial ecosystems-a review. Mitig Adapt Strateg Glob Change 11:395-419

45. Liang B, Lehmann J, Solomon D, Kinyangi J, Grossman J, O'Neill B, Skjemstad JO, Thies J, Luizao FJ, Petersen J, Neves EG (2006) Black carbon increases cation exchange capacity in soils. Soil Sci Soc Am J 70:1719-1730

46. Liu G, Zheng H, Wang Z (2014) Analysis of material properties with biochar improve indian mustard (Brassica juncea) growth in acidic soil in Northern China. Appl Mech Mat 540:239-242

47. Liu X, Hua W, Wu S (2016) Characterization of thermo-chemical degradation and pyrolysis properties for three kinds of biomass residues. Bio Res 11:8806-8819

48. Lou Y, Joseph S, Li L, Graber ER, Liu X, Pan G (2016) Water extract from straw biochar used for plant growth promotion: an initial test. Bio Resour 11:249-266

49. Lü J, Li J, Li Y, Chen B, Bao Z (2012) Use of rice straw biochar simultaneously as the sustained release carrier of herbicides and soil amendment for their reduced leaching. J Agric Food Chem 60:6463-6470

50. Meschewski E, Holm N, Sharma BK, Spokas K, Minalt N, Kelly JJ (2019) Pyrolysis biochar has negligible effects on soil greenhouse gas production, microbial communities, plant germination, and initial seedling growth. Chemosphere 228:565-576

51. Meyer S, Glaser B, Quicker P (2011) Technical, economical, and climate-related aspects of biochar production technologies: a Literature Review. Environ Sci Technol 45:9473-9483

52. Manolikaki I, Diamadopoulos E (2020) Agronomic potential of biochar prepared from brewery byproducts. J Environ Manage 255:109856

53. Nieva ML, Volpe MA, Moyano EL (2015) Catalytic and catalytic free process for cellulose conversion: fast pyrolysis and microwave induced pyrolysis studies. Cellulose 22:215-228

54. Nieva Lobos ML, Piloni RV, Alarcón AA, Leal LE, Alarcón R, Moyano EL (2020) Fast pyrolysis of biomass: a sustainable process to produce bio-oils with antifungal and antioxidant properties (Unpublished results)
55. Novak JM, Busscher WJ, Laird DL, Ahmedna M, Watts DW, Niandou MA (2009) Impact of biochar amendment on fertility of a southeastern Coastal Plain soil. Soil Sci 174:105-112

56. Oguntunde PG, Abiodun BJ, Ajayi AE, van de Giesen N (2008) Effects of charcoal production on soil physical properties in Ghana. J Plant Nutr Soil Sci 171:591-596

57. Oleszczuk P, Jośko I, Kuśmierz M (2013) Biochar properties regarding to contaminants content and ecotoxicological assessment. J Hazard Mater 260:375-382

58. Ortega-Calvo JJ, Mazuelos C, Hermosin B, Saiz-Jimenez C (1993) Chemical composition of Spirulina and eukaryotic algae food products marketed in Spain. J Appl Phycol 5:425-435

59. Park CS, Erickson DO, Fisher GR, Haugse CN (1982) Effects of sunflower hulls on digestibility and performance by growing dairy heifers fed varying amounts of protein and fiber. J Dairy Sci 65:52-58

60. Peterson SC (2013) Utilization of low-ash biochar to partially replace carbon black in styrene-butadiene rubber composites. J Elastom Plast 45:487-497

61. Piloni RV, Brunetti V, Urcelay RC, Daga IC, Moyano EL (2017) Chemical properties of biosilica and bio-oil derived from fast pyrolysis of Melosira varians. J Anal App Pyrol 127:402-410

62. Qian L, Chen L, Joseph S, Pan G, Li L, Zheng J, Zhana X, Yu X, Wang J (2014) Biochar compound fertilizer as an option to reach high productivity but low carbon intensity in rice agriculture of China. Carbon Manag 5:145-154

63. Rogovska N, Laird D, Cruse RM, Trabue S, Heato E (2012) Germination tests for assessing biochar quality. J Environ Qual 41:1014-1022

64. Rombolà AG, Marisi G, Torri C, Fabbri D, Buscaroli A, Ghidotti M, Hornung A (2015) Relationships between chemical characteristics and phytotoxicity of biochar from poultry litter pyrolysis. J Agric Food Chem 63:6660-6667

65. Roy C, De Caumia B, Pakdel H (1988) Preliminary feasibility study of the biomass vacuum pyrolysis process. In: Bridgwater AV (ed) Research in Thermochemical Biomass Conversion. Elsevier Science Publisher, Amsterdam, pp 585-596

66. Ruan J, Huang J, Qin B, Dong L (2018) Heat transfer in vacuum pyrolysis of decomposing hazardous plastic wastes. ACS Sustain Chem Eng 6:5424-5430

67. Saleh ME, El-Refaey AA, Mahmoud AH (2016) Effectiveness of sunflower seed husk biochar for removing copper ions from wastewater: a comparative study. Soil Water Res 11:53-63

68. Silva MP, Moyano EL, Scopel AL (2017) Potential applications of biochar and terpene-enriched bio-oil produced from a semiarid native Asteraceae. J Anal App Pyrol 126:39-49

69. Smith CR, Buzan EM, Lee JW (2012) Potential impact of biochar water-extractable substances on environmental sustainability. ACS Sustain Chem Eng 1:118-126

70. Smith C, Sleighter R, Hatcher P, Lee J (2013) Molecular characterization of inhibiting biochar water-extractable substances using electrospray ionization fourier transform ion cyclotron resonance mass spectrometry. Environ Sci Technol 47:13294-13302

71. Song Y, Bian Y, Wang F, Xu M, Ni N, Yang X, Gu C, Jiang X (2017) Dynamic effects of biochar on the bacterial community structure in soil contaminated with polycyclic aromatic hydrocarbons. J Agric Food Chem 65:6789-7679

72. Sorgonà A, Longo L, Proto AR, Cavalletti P, Cecchini M, Salvati L, Gallucci F, Colantoni A (2016) Characterization of biochar and syngas obtained from pellets of grape vine and sun flower husk using a pyrolysis system. Procedia - Soc. Behav Sci 223:871-878

73. Spokas KA, Novak JM, Stewart CE, Cantrell KB, Uchimiya M, DuSaire MG, Ro KS (2011) Qualitative analysis of volatile organic compounds on biochar. Chemosphere 85:869-882 
74. Strezov V, Patterson M, Zymla V, Fisher K, Evans TJ, Nelson PF (2007) Fundamental aspects of biomass carbonization. J Anal Appl Pyrolysis 79:91-100

75. Sun J, Drosos M, Mazzei P, Savy D, Todisco D, Vinci G, Pan G, Piccolo A (2017) The molecular properties of biochar carbon released in dilute acidic solution and its effects on maize seed germination. Sci Total Environ 576:858-867

76. Zabaniotou AA, Kantarelis EK, Theodoropoulos DC (2008) Sunflower shells utilization for energetic purposes in an integrated approach of energy crops: laboratory study pyrolysis and kinetics. Biores Technol 99:3174-3181

77. Tana Z, Lin CSR, Ji X, Rainey T (2017) Returning biochar to fields: A review. Appl Soil Ecol 116:1-11

78. Tomczak E, Tosik P (2017) Waste plant material as a potential adsorbent of a selected azo dye. Chem Process Eng 38:283-294

79. Tomczyk A, Sokołowska Z, Boguta P (2020) Biochar physicochemical properties: pyrolysis temperature and feedstock kind effects. Rev Environ Sci Biotechnol 19:191-215

80. Uchimiya M, Lima IM, Klasson KT, Chang SC, Wartelle LH, Rodgers JE (2010) Immobilization of heavy metal ions (Cull, Cdll, Nill, and Pbll) by broiler litter derived biochars in water and soil. $J$ Agric Food Chem 58:5538-5544

81. Uchimiya M, Liu Z, Sistani K (2016) Field-scale fluorescence fingerprinting of biochar-borne dissolved organic carbon. J Environ Manag 169:184-190
82. Van Soest PJ (1975) Physico-chemical aspects of fibre digestion. In: McDonald IW, Warner ACl (eds) Digestion and Metabolism in the Ruminant. University of New England Publishing Unit, Armidale, Australia, pp 351-365

83. Wang X, Xing B (2007) Sorption of organic contaminants by biopolymer-derived chars. Environ Sci Technol 1:8342-8348

84. Xie H, Yu Q, Qin Q, Zhang H, Fu X (2013) Bio-oil production by fast pyrolysis from agriculture residue in northeastern. Chin J Renew Sustain Energy 5:013103

85. Yao Y, Gao B, Zhang M, Invang M, Zimmerman AR (2012) Effect of biochar amendment on sorption and leaching of nitrate, ammonium, and phosphate in a sandy soil. Chemosphere 89:1467-1471

86. Zheng W, Guo M, Chow T, Bennett DN, Rajagopalan N (2010) Sorption properties of greenwaste biochar for two triazine pesticides. J Hazard Mater 181:121-126

Publisher's Note Springer Nature remains neutral with regard to jurisdictional claims in published maps and institutional affiliations. 